Di Domizio, Marco. Football on TV: an empirical analysis on the italian couch potato attitudes.

\title{
FOOTBALL ON TV: AN EMPIRICAL ANALYSIS ON THE ITALIAN COUCH POTATO ATTITUDES
}

\section{FÚTBOL EN LA TELEVISIÓN: UN ANÁLISIS EMPÍRICO SOBRE LAS ACTITUDES COACH POTATO DE LOS ITALIANOS}

\author{
Marco Di Domizio \\ Researcher in Economics \\ Faculty of Political Sciences \\ University of Teramo, Italy \\ mdidomizio@unite.it
}

Fecha de recepción: febrero de 2013

Fecha de aceptación: mayo de 2013

\begin{abstract}
This paper investigates the relationship between Football and TV audience looking for empirical evidences from Italian Serie $A$. The analysis traces previous econometric study, based on season 2008/09, focusing on season 2009/10. Data on 380 matches played in the Italian top professional football league are collected in order to select variables suitable of influencing the share of TV audience on satellite television. We try to estimate the «Football on TV» demand by an OLS regression model introducing a set of independent variables about the match quality, the TV programming placement, the market size of teams and their rank. In addition, our attention concentrates on the relationship between the closeness of the game and the television audience, where uncertainty of outcome is modelled using information from the betting market. It emerges that many of the theoretical expected relationships are confirmed by the econometric analysis, even though some peculiarities emerge with respect to the uncertainty of outcome issue. In particular, closer contexts are important in determining the interest of sporting events, also from the Italian TV audience perspective, but they are not crucial.

If the set of explanatory variables includes both the uncertainty of outcome and teams probabilities of winning, a negative relationship between the closeness of the match and TV audience emerges. This result suggests two possible explanations. First, the TV spectators behave just like stadium fans, and they are mainly interested in their own team victory. Second, the negative relationship may be attributed to the "David versus Goliath» hypothesis since neutral positioned fans watch matches on TV in the hope that little teams defeat top ranked teams. Finally, our empirical analysis confirms the decisive role of Inter, Juventus and Milan in determining the size of couch potato audience, supporting the idea of big teams' management that the competitive balance has not a great commercial appeal, and that the collective bargaining of TV rights must not be justified on this ground.
\end{abstract}

KEY WORDS: television, audience, football, Italy, couch potato. 
Di Domizio, Marco. Football on TV: an empirical analysis on the italian couch potato attitudes.

\section{RESUMEN}

En este trabajo se investiga sobre la relación entre el fútbol y las audiencias televisivas en búsqueda de evidencias empíricas de la Serie $A$ italiana. El análisis esboza un estudio econométrico previo basado en la temporada 2008/09, y se centra en la temporada 2009/10. Se ha recabado información de 380 partidos jugados en la liga de fútbol profesional con el fin de seleccionar variables de influencia para determinar el share de la audiencia televisiva en televisión por satélite. Se ha intentado determinar la demanda de "fútbol en televisión" mediante un modelo de regresión OLS que introduce una serie de variables independientes que determinan la calidad del partido, del lugar que ocupe en la programación televisiva, el mercado que tenga cada uno de los equipos participantes y el lugar que ocupan dentro del ranking deportivo. Adicionalmente, nuestra atención se centra en la relación entre la cercanía del juego y la audiencia televisiva, en donde la falta de certeza sobre el resultado es sustituida por previsiones provenientes del mundo de las apuestas. De esta manera, muchas de las relaciones teóricas que se esperan son confirmadas por el análisis econométrico, aun cuando algunas peculiaridades surjan con respecto a la falta de certeza del resultado del evento. En particular, los contextos más cercanos son importantes para determinar el interés de los eventos deportivos, también desde una perspectiva de la audiencia italiana de televisión, aunque estos no sean en principio determinantes.

Si el conjunto de las variables explicativas incluyen tanto la falta de certidumbre sobre el resultado final como las probabilidades del equipo de ganar, se da una relación negativa entre la proximidad del partido y las audiencias televisivas. Este resultado sugiere dos posibles explicaciones: En primer lugar, los televidentes se comportan como hinchas en el estadio, y están interesados básicamente en la victoria de su propio equipo. En segundo lugar, la relación negativa puede atribuirse a la hipótesis de "David contra Goliat", ya que aquellos fans posicionados neutralmente ven los partidos en televisión con la esperanza de que los pequeños equipos venzan a los equipos mejor posicionados. Finalmente, nuestro análisis empírico confirma el rol decisivo de equipos como el Inter, la Juventus o el Milan a la hora de determinar el tamaño de la audiencia "coach potato", apoyando la idea que sustenta la gestión de los grandes equipos en cuanto a que el equilibrio competitivo no tiene un gran atractivo comercial, y que la negociación colectiva de los derechos deportivos en televisión no debe justificarse en este supuesto.

PALABRAS CLAVE: televisión, audiencia, fútbol, Italia, "couch potato"

\section{INTRODUCTION}

The interaction between Media and Professional Sports Leagues is a significant matter of the sports economics literature. Several books, papers and journal articles concentrate on the role of broadcasting sporting events live, particularly on the financial opportunities for teams and leagues, on the consequences about the intraleague competitive balance, and on the long period leagues organization ${ }^{1}$. Up to the end of $80 \mathrm{~s}$ the literature was almost exclusive of the North-American sports professional context, since the sphere of influence of TV broadcasters on European sports was restricted to some big events at the international level. In 1992 the

\footnotetext{
${ }^{1}$ On the connection between Sports and Media see Cave and Crandall (2001), Jeanrenaud and Kesenne (2006), chapter 3 in Fort (2006), chapter 6 in Sandy, Sloane and Rosentraub (2004), Buraimo (2006), Noll (2007).
} 
Di Domizio, Marco. Football on TV: an empirical analysis on the italian couch potato attitudes.

change of the English Football League (EFL) in English Premier League (EPL) opened new scenarios for the European football organization. The reform of the EFL was explicitly launched to increase the power of larger clubs in the TV rights bargaining, taking into account the new opportunities provided by the competition in TV market ${ }^{2}$. It was only the begin of a period of great changes in the European sports environment, particularly in the football scenario. As a consequence, the revolution influenced the Italian football professional leagues, including both financial and organizational features. From an economic perspective, in the decade across the new century, the production value of the Italian football industry (the aggregate revenues of all teams in the four professional divisions) increased more then twofold from about $€ 870 \mathrm{mln}$ in 1997 to $€ 1,752 \mathrm{mln}$ in 2006 (in current value) ${ }^{3}$. The last Italian Football Federation Report fixes at $€ 2.5$ bln the aggregate revenues of the Italian professional system ${ }^{4}$. The exponential rise is the consequence of the growth of the commercial value of TV rights that, at the present, accounts on average for more than $50 \%$ of the total revenues ${ }^{5}$. In addition, the Italian top teams competing in Serie $A$ increased exponentially TV returns thanks to the opportunity of individual negotiation of TV rights, after the pronunciation of Italian antitrust authority (AGCM) in 1999 imposing the league the stop of the collective bargaining of not free-to-air rights $^{6}$. This caused a radical change in the returns composition of teams, reducing the share of gate revenues on total entrances from $1 / 3$ in 1998/99 to $1 / 10$ in the season 2010/11. Broadcasting proceeds became the main resource of Italian teams, mainly for those competing at international level. The recent report on financial performance of European Top 20 Clubs, based on data 2011/12, shows that about $54 \%$ of total revenues of the Italian top teams comes from TV rights, while the average for non-Italian teams is about $37.5 \%{ }^{7}$. Together with TV revolution, other changes occurred in different areas: in the number of teams competing in Serie $A$ and $B$, in the opportunity of hiring extra foreigners players, in the time placement of matches, in the anti-violence strategies introduced in $2007^{8}$. The changes have come with political and organizational worries, social tensions and legislative interventions aiming to compose the transformations in progress, often without success ${ }^{9}$. If the financial viewpoint concentrates on the business opportunities, the economic literature is interested in two topics coming from the connection «Sport \& Television». The first relates to the presumed crowding-out effect on gate attendance caused by broadcasting matches live; the second refers to the analysis of TV audience nature compared with the stadium fans attitude. As suggested by Szymanski (2001), the latter issue is of relevance since it aims to achieve information about the presumed uncommitted nature of TV spectators compared with the committed attitude of stadium fans. This way, given the importance that broadcasters assumed in

\footnotetext{
${ }^{2}$ For a brief history of changes in the United Kingdom sports broadcasting scenario see section 2.5 in Dobson and Goddard (2001) and chapter 8 in Downward and Dawson (2000). For the financial perspectives of EPL see Gerrard (2006).

${ }^{3}$ At constant prices, using Consumer Price Index (CPI) provided by the Italian Institute of Statistics (ISTAT), the ratio between total revenues in 2006 and 1997 is 1.66 .

${ }_{5}^{4}$ FIGC Report 2012, available on www.figc.it (June, 2012).

${ }^{5}$ For a discussion on the financial and commercial outlook of the Italian Serie A see Venturelli (2009) and Nicoliello (2008).

${ }^{6}$ For an exhaustive juridical survey on Italian TV rights history see Figus Diaz and Forti (2008) and Tonazzi (2003). On the role of broadcasting rights scheme and competitive balance see Peeters (2009).

${ }^{7}$ Deloitte, Captains of Industry - Football Money League, March 2013, available on www.deloitte.co.uk.

${ }^{8}$ On anti-violence policy and its detrimental effect on attendance see Caruso and Di Domizio (2012).

${ }^{9}$ See Hoen and Szymanski (2001) for the debate at European level and Beha and Di Caro (2006), Tavella (2006) and Boeri and Bisoni (2009) for the problems of the Italian football system.
} 
Di Domizio, Marco. Football on TV: an empirical analysis on the italian couch potato attitudes.

determining financial and organizational behaviour of leagues, it is not possible to think of leading changes ignoring the preferences of a key football character: the couch potato audience. The relevance of that issue also comes from the presence of two phenomena characterizing the Italian Serie $A$ from the early 90s: a general reduction in gate attendance combined with an increase of competitive unbalance ${ }^{10}$. According to seminal contributions, ${ }^{11}$ the uncertainty of outcome plays a key role for the success of team sports organized in leagues, influencing the appeal of the sporting context and financial returns. Obviously, the competitive balance mainly depends on the resources that TV broadcasters make available to each single club. Simulations on the current season (2012/13), show that more than $43 \%$ of total resources coming from TV rights will be attributed to the top 5 teams. This means that more than $€ 400$ mln will be shared by Juventus, Milan, Inter, Napoli and Roma, while the remaining part (about $€ 450 \mathrm{mln}$ ) will be allocated among the others 16 teams. The unequal allocation of TV revenues has its counterpart in the talent distribution over teams; the above mentioned teams pay more than 55 per cent of the league's aggregate net wages ( $€ 483 \mathrm{mln}$ over an aggregate value of $€ 866.3 \mathrm{mln})^{12}$. What is the role of the television in determining talent distribution among teams? Is the television responsible for the reduction in competitive balance? If so, is the television guilty for the decreasing appeal of Italian football? To reply other issues must be considered. First, the idea of a greater appeal of more uncertain matches has not been confirmed on the empirical ground. As we discuss later, the relationships between the closeness of the game and the gate attendance and TV audience is suitable to assume several functional forms and derivative signs, not always in the expected direction. ${ }^{13}$ Second, is it sure that the TV crowds-out gate attendance? Third, as Jeanrenuad and Kesenne wonder: "Are demand determinants for televised sport the same as those for live attendance?» ${ }^{14}$

Our paper focuses mainly on the third point; as in our previous contribution, based on data 2008/09 [Di Domizio (2012)], we tries to investigate the relationships between TV audience and a set of variables able to influence couch potato preferences using an OLS model to identify, if anyone, their statistical significance and magnitude. The paper is organized as follows: section 1 resumes the literature on the relationships between Sports and Media, section 2 concentrates on the Italian football context, section 3 describes the variables used in our estimates and section 4 discusses the main results. Section 5 concludes the paper.

\section{THE RELATIONSHIP BETWEEN SPORTS AND TV: AN OVERVIEW}

The relationship between Mass Media and Sport is considered a key topic to analyse, and the role played by broadcasters in determining the organizational patterns of sporting events is widely debated in the literature. As known, for example, in the United States the richest four professional leagues (NFL, NBA, MBL and NHL) owe their format to the 1961 Sport Broadcasting Act that settled some exemption to

\footnotetext{
10 See Di Domizio (2007). On the competitive balance role in Serie $A$ see also Haan, Koning and Van Witteloostuijn (2008) and Brandes and Franck (2007).

${ }^{11}$ See Neale (1964), El-Hodiri and Quirk (1971).

${ }^{12}$ Source: La Gazzetta dello Sport, 11/09/2012.

${ }^{13}$ See Borland and Macdonald (2003), Villar and Guerrero (2009), Buraimo and Simmons (2008), Pérez and Rodriguez (2012).

${ }^{14}$ Jeanrenaud and Kesenne (2006, p. 3).
} 
Di Domizio, Marco. Football on TV: an empirical analysis on the italian couch potato attitudes.

the antitrust rules concerning other industries; this in order to preserve the fan interest by protecting the competitive balance and the league survival ${ }^{15}$. Neglecting law, economic and political issues determining the key position of broadcasters on North-American professional sports, we concentrates on two issues.

First, the presumed crowding-out effect of the live televised matches on gate attendance. This is not a simple issue to sort out. Of course, a certain degree of substitution exists between televised and live matches ${ }^{16}$; at the same time the opportunity of being part of the show may support the stadium attendance. Applying a league perspective, Baimbridge, Cameron and Dawson (1996) try to compose the query analysing the impact of live transmission of 60 out of 462 EPL matches played in 1994/95 season. They find, on average, a reduction on gate attendance of $15 \%$ and two other interesting results: $l)$ the negative influence of televised matches on gate attendance is significant only on Monday; ii) the single match revenue losses caused by the crowding-out effect is marginal compared to the TV entrances shared by teams for their TV appearance. Forrest, Simmons and Szymanski (2004) analyse the attendance in EPL and English First Division from 1992/93 to 1997/98 and estimate a crowding-out effect for Monday Night matches around $9 \%$ and between 10 and 18 per cent in the First Division under free-to air coverage. Forrest and Simmons (2006) concentrate on the presumed cannibalisation of EPL and European Cups versus the other three English football league divisions. They support the idea of a strong crowding-out effect on gate attendance of about 21 and 16 per cent, respectively for Second Division and Third Division for matches played simultaneously with Champions League date when British clubs play. Furthermore, Buraimo, Forrest and Simmons (2006) estimate a reduction in gate attendance about 23 per cent for matches broadcasted by free-to-air television, and about 5 per cent for matches broadcasted on satellite television in the $2^{\text {nd }}$ Tier of the four English professional leagues. More recently Allan and Roy (2008) seize a negative impact of televised matches on home-fans gate attendance of about $30 \%$ in the Scottish League. Garcia and Rodriguez (2002), concerning the Spanish Primera División, estimate a negative impact of the televised matches on gate attendance of 33 per cent for free-to-air broadcasted matches, and 45 per cent for matches on satellite television. Buraimo and Simmons (2007), for the same league, although for different periods, calculate a negative impact of the televised matches on gate attendance of 5 per cent on weekdays and of 3 per cent during the weekend, but only for public television coverage; on the contrary, no statistically significant effects of cable or satellite broadcasting emerge. From Santana and Silva (2009) no substitution effect of televised matches on gate attendance appears in the Brazilian Championship.

The second issue refers to the uncertainty of outcome relevance in determining the audience of sporting events on television. Sincerely, the interest for the relationship between competitive balance and sporting events appeal is rather remote, and may be ascribed to Neale (1964) in one of the key contributions of sports economics literature. We refer to the famous Louis-Schmelling paradox asserting the relevance of closing contexts to promote the success of the leagues. This opinion grounds on

\footnotetext{
${ }^{15}$ An opposite viewpoint is expressed by Perlasca (2006).

16 A remarkable example reported in many textbooks refers to the Philadelphia Eagles which suffered a reduction in gate ticket sales of about $50 \%$ in the 1948 season after the decision to broadcast all their home games, inducing the NFL to adopt the "black out" rule for not sold out matches. See Leeds and Von Allmen (2005).
} 
Di Domizio, Marco. Football on TV: an empirical analysis on the italian couch potato attitudes.

the hypothesis that a less uncertain context is detrimental for fan interest, inducing a reduction in gate attendance, magazines sales, TV audience, merchandising activities and so on. This way, great efforts of sports economics literature is devoted to test this hypothesis empirically, and a comprehensive survey is reported in Szymanski (2003), Borland and Macdonald (2003) and in Villar and Guerrero (2009). According to these contributions, results appear quite heterogeneous, among different sports and different leagues, depending on the variables chosen as a proxy for the uncertainty of outcome. Briefly, in 39 empirical works analyzed in the survey of Borland and Macdonald, only 15 confirm a significant and positive relationship between uncertainty of outcome and gate attendance. If we concentrate only on football scenario (12 out of 39), in 5 papers the positive correlation is confirmed, while the remaining 7 show $U$-shaped or inverse functional form. On this ground the call for the introduction of measures shielding the competitive balance within the leagues may not be supported by invoking strict preferences of stadium fans for uncertain contexts. The same result appears for the Italian Serie $A$, where no statistical significance emerges between the closeness of the match, measured by absolute difference of winning probabilities, and gate attendance [Caruso and Di Domizio (2012)].

The empirical analysis of the relationship between uncertainty of outcome and television audience has been less practised because the opportunity of watching matches on TV live is relatively recent, and data sets need to be implemented, both in quality and extent. Forrest, Simmons and Buraimo (2005) focus on the relevance of uncertainty both for TV management broadcasting strategies and TV audience selection, introducing a new measure of outcome uncertainty based on the points per-game achieved by the teams, corrected by the home field advantage. From the couch potato audience perspective they conclude that "outcome uncertainty does matter for the English Premier League [...] but only up to a point" (p.660). Buraimo and Simmons (2007) support the outcome uncertainty hypothesis for TV audience, with the exclusion of matches involving Barcelona, attributing this attitude to the fact that "Television viewers will contain a large group of spectators who have at best a loose affinity to either team and prefer to see a close game" (p.18). Using Gerrard's expression (2006, p.34-35) we can conclude that "in order to assess the practical policy implications of the economic analysis of competitive balance, there is a better understanding of the determinants of fan demand [...] future research needs to clarify the nature and behavioural significance of the concepts of uncertainty of outcome, competitive balance and contest significance [...] differentiating between team fans and game fans in the analysis of the demand behaviour of sports fans".

\section{THE CONNECTION BETWEEN FOOTBALL AND TELEVISION IN ITALY}

The Italian football organization was involved, in the decades across the end of the century, in great transformations, inducing the observers to coin the slogan From Game to Business ${ }^{17}$. This in order to emphasize the role of the financial flaws shared out in the Italian Serie $A$, following the revolutionary changes caused by the entrance of new broadcasting platforms in the early 90s: respectively pay-tv in 1993, pay-perview in 1996 and the attribution by the Antitrust Authority of pay-per-view, pay-TV

\footnotetext{
${ }^{17}$ See Lago, Baroncelli and Szymanski (2004).
} 
Di Domizio, Marco. Football on TV: an empirical analysis on the italian couch potato attitudes.

and international rights to each single teams in $1999^{18}$. This changes offered to Italian fans, for the first time ever, the opportunity to watch matches on television live. At the beginning, from 1993 to 1996, only one or two matches, played in advance on Saturday night or postponed on Sunday or Monday night, were broadcasted on satellite platform. From 1996 on, the entrance of the pay-per-view technology disclosed the chance of watching live all the matches ${ }^{19}$. As a consequence, the annual TV entrances of Serie $A$ and Serie $B$ moved from $€ 50 \mathrm{mln}$ in the 1992/93 up to $€ 1.13$ bln in the season $2010 / 11$. This way, the season $1996 / 97$ was the turning point of the Italian financial football organization; for the first time ever the TV rights entrances (€204 $\mathrm{mln}$ ) exceeded the revenues from gate attendance (€176 mln). In spite of the massive flaw of resources the Italian football system was not able to generate profits of the same size $\mathrm{e}^{20}$. The football managers and owners spent great part of the TV revenues hiring new players and increasing exponentially salaries, neglecting old and new entrances, respectively gate and merchandising receipts. The distance in revenues distribution in favour of TV entrances was undoubtedly amplified by the transition from a centralized regime of encrypted TV rights to the subjective rights imposed by the Law 29 March 1999 n.78, composing a series of declarations of the Italian Antitrust Authority $(\mathrm{AGCM})^{21}$. The decentralized regime of encrypted TV rights starting from 1999 generated a strong unbalance in the resources collected by Italian teams playing in Serie $A$ in favour of big teams generating a first to last ratio of about 9 to 1 in 2002. The medium and little teams complaints and a new political approach yielded a legislative intervention, ratified by Law 9 January 2008 n.9, reintroducing the collective bargaining from the season $2010 / 11$, in hopes of a more balanced distribution of TV resources among teams. But the conflict among little/medium and big teams remains. On one hand Juventus, Inter and Milan invoking a prominent role in organizational and resource distribution sphere, since they believe that the commercial value of the league depends almost exclusively on themselves. On the other hand the medium and little teams disagree with big teams approach claiming the joint nature of league production.

Our goal is to support or oppose, on the empirical ground, the arguments of teams testing the hypothesis that TV audience is fascinated by uncertain contexts or, on the contrary, if the couch potato is mainly interested in the top team performances. Roughly speaking, how does the competitive balance and hence more (ex-ante) uncertain matches influence the TV audience in Italy?

\footnotetext{
${ }^{18}$ On the role played by the television in determining the current Italian and other European leagues organization see Andreff and Bourg (2006).

${ }_{19}$ At first, in order to protect gate attendance from TV competition, some restrictions were introduced as black out in the province where the matches were played, but this rule was soon cancelled. Today, Italians equipped with a satellite dish and a subscription for a TV sports contract with SKY (SKY CALCIO), may have access to all matches played in Serie A. This opportunity is extended to the Italians equipped with a digital terrestrial decoder and a TV subscription with digital channel (MEDIASET PREMIUM) but only for selected teams.

${ }^{20}$ This assertion could be easily shrunk invoking the utility oriented attitude of Italian teams compared to the profit oriented one [Sloane (1971)]. On the other hand the private amusement of several Italian owners could benefit from State aid thanks to the law 21 February 2003 n.27, known as decreto spalmadebiti, that introduced accounting and financial concessions to the professional teams lying heavily on Italian taxpayers.

${ }^{21}$ See measure $1^{\text {st }}$ July 1999 n.7340 - I362 of AGCM relative to TV rights bargaining.
} 
Di Domizio, Marco. Football on TV: an empirical analysis on the italian couch potato attitudes.

\section{TELEVISION AUDIENCE IN ITALY: AN EMPIRICAL INVESTIGATION}

This section investigates the preference of the Italian couch potato audience; above all we try to evaluate which variables influence the television audience of the Italian Serie $A$. Our goal is to identify similarities or differences of the Italians preference with respect to those emerged in other European contexts. This in order to support or oppose Italian top teams' arguments about their decisive role in determining the success and hence the commercial appeal of football on TV, net of competitive balance effects.

The empirical investigation focuses on matches played in Serie $A$ in the season 2009/10, from August 2009 till May 2010, and follows previous analysis on season 2008/09 [Di Domizio (2012)]. Data on TV audience refer to the satellite channels (SKY), officially provided by the National Professional League (LNP - Lega Nazionale Professionisti) on its website. The choice of evaluating the TV audience by the use of satellite television data depends on several points. First, with respects to other European competitions where only a restricted number of matches are televised live, the coverage of matches played in Serie $A$ is all-inclusive, even if depending on the SKY-pack purchased. In the referring season the SKY platform broadcasted all matches, while the same was not for other digital channel such as MEDIASET PREMIUM, where only matches involving a restricted number of teams were broadcasted. The SKY CALCIO-pack subscribers buy the right of watching all matches live on their satellite channel. They must be differentiated by the other SKY SPORT-pack subscribers that may watch only advanced (on Saturday evening and night) or postponed (on Sunday night) matches and one or two matches (selected randomly) of the traditional fixed time on Sunday evening. Data provided by LNP include the cumulative share registered by SKY signalling by a star those matches televised on various channels (SKY CALCIO and SKY SPORT). The second rationale for choosing satellite television audience is based on price. Each subscriber of the SKY CALCIO or SKY SPORT-pack pays a fixed amount (usually with monthly frequency for a period of one year), thus the marginal cost of watching a single match is null. This is not (always) true for digital television platforms where, together with the opportunity of subscribing to an all-inclusive pack (for selected teams), it is possible to buy the right for a single match deducting a certain amount (in the season under investigation for about €7/8) from a pay-as-you-go card. The third reason supporting the satellite television audience selection bases on the precision and regularity of data provision since the audience of SKY is checked by the official institute monitoring all Italian TV programming (AUDITEL), while data on digital television audience, at that time, were not available. The satellite television audience registered by SKY is provided by $L N P$ in form of absolute number of audience and the share. In our econometric estimation we consider the share (Share) in order to elude biases caused by the growth of subscribers.

To identify factors influencing the TV audience we follow previous literature suggestions on theme, and include some Italian scenery topics selecting both sports, teams and programming variables. For example, note that 3 out of 10 matches of each round are played in advance or postponed with respect to the traditional date on Sunday evening ${ }^{22}$. Two matches are played on Saturday evening and night,

\footnotetext{
${ }^{22}$ In the season $2009 / 10$ only the matches of the last two rounds have been played at the same time in order to avoid potential fraud, with the exemption of Juventus-Milan and Lazio-Udinese.
} 
Di Domizio, Marco. Football on TV: an empirical analysis on the italian couch potato attitudes.

usually by teams engaged with the Champions League tournament in the succeeding Tuesday ${ }^{23}$; one match, chosen by the management of SKY, is postponed on Sunday night. Our opinion is that the TV programming placement must be not neglected to evaluate the appeal on audience since the matches played in advance or postponed do not have perfect substitutes. We then introduce the dummy Advanced or Postponed and the expectation on the sign of its coefficient is positive. In addition, we consider that the advanced and postponed matches may be watched on satellite TV both by subscribers of SKY CALCIO and SKY SPORT-packs, while the matches played on Sunday evening are exclusive of the formers. However SKY SPORT-pack subscribers may watch one or two matches played on Sunday evening, selected randomly by SKY, increasing the potential audience of the match. If so, a dummy Plus is added signalling matches broadcasted on both channels in order to isolate the positive effect of reaching a more inclusive audience. A third thought about the TV programming refers to the time and seasonal arrangement of matches. First, it is not rare that, given the intensive sporting schedule, some rounds are played in the middle of the week or in other working days. It is our opinion that the middle week collocation may influences negatively the audience, and for this reason we introduce a dummy, Working Day, identifying matches not played on Saturday and Sunday. In addition, we introduce a seasonal dummy Winter pointing out matches played in the coldest months of the year, from November to February. Our expectation is for a positive influence of Winter dummy on TV audience since many fans ought to prefer comfortable home environment with respect to that in the stadium. Again, a Trend variable fixes the progression of the championship since a possible decrease in the interest may arise when ranks in the standing become stable.

Adding variables have a typical sporting character. The first relates to the expected quality of the match. Following Hall, Szymanski and Zimbalist (2002), Forrest, Simmons and Buraimo (2005) and Buraimo and Simmons (2008) for the British context, and Szymanski (2004) for the Italian environment, we introduce the payroll of each single team as a proxy for the talent magnitude and hence the teams/matches quality. This because of the strong correlation emerged in the previous empirical contributions between salaries and teams' performances. Note that the information about teams' payroll is poor since only public traded teams are forced in its publication, and the only homogeneous data at single team level are provided by journalistic source ${ }^{24}$. To size the quality of each single match, we the introduce the Combined Wages, indicated as $C W G_{i}$, where $i$ refers to the $i$-th match played $^{25}$. The $C W G_{i}$ variable is calculated as follows:

$$
C W G_{i}=R W G_{H i} \cdot R W G_{A i}
$$

where $R W G_{H i}$ and $R W G_{A i}$ indicates the relative amount of net wages, respectively of home team and away team, engaged in the $i$-th match, and relative values are obtained as:

\footnotetext{
${ }^{23}$ Often teams engaged with Champions League matches play on Friday night.

${ }^{24}$ This is the case of Montanari and Silvestri (2007).

${ }^{25}$ Data on team payrolls come from La Gazzetta dello Sport, September 2010.
} 
Di Domizio, Marco. Football on TV: an empirical analysis on the italian couch potato attitudes.

$$
R W G=\frac{W G}{A W G}
$$

where $W G$ is the value of total (net) wages paid by the team and $A W G$ the average net payroll of the league in the season under investigation. This specification adheres to that used by Forrest, Simmons and Buraimo (2005) and summarizes the quality of talent for each single match. The Combined Wages is an index increasing in the average quality of talent, and the expectation is for a positive sign of the coefficient associated. In addition, with respect to match quality, we include a variable for the attractiveness of the match based on the expected number of goals. We introduce the betting odd associated to the event "more than 2.5 goals" (Over 2.5$)^{26}$. Note that an increase in Over 2.5 indicates a reduction in the expectation of the number of goals scored and, consequently, the expected sign is negative. A third sporting related variable refers to the uncertainty of outcome. As suggested by Pope and Thomas (1989), Peel and Thomas (1992), and Czarnitzki and Stadtmann (2002), Alavy, Gaskell, Leach and Szymanski (2010), we acquire information about the closeness of the game using betting data. Data are collected from Football-Data archive which provides the more inclusive data set on European football betting odds market ${ }^{27}$. On the opportunity and lacks of using betting odds as a proxy for measuring match uncertainty we refer to Forrest and Simmons (2002). As a proxy for the closeness of the game we use the difference between the home team and the away team win probabilities, in absolute value, named Absolute Probability Difference. As known, the betting odds on football match results appear as a multiplying factor of the sum paid by the better to the bookmaker. The probabilities are then calculated by inverting the odds and taking into account the mark-up of the betting agencies. Obviously, an increase in the Absolute Probability Difference indicates less uncertainty of outcome, so the expected sign in the relationship with TV audience is negative. In addition, the Home Team Win Probability is included in the regression, both in linear and in squared (Squared Home Team Win Probability). This in order to meet the empirical evidence, emerged in several football contexts, suggesting a potential $U$-shaped relationship between attendance and team winning expectation. Given the opportunity offered by television to easily reach away team fans we also estimate a model including the Away Team Win Probability (in linear and squared value) instead of the home team probabilities. Together with the uncertainty of outcome we aim at isolating the potential "superstar» effect on TV audience. As suggested by Dobson and Goddard (2001, p 424) "Inevitably the television coverage was skewed in favour of the clubs with the most followers, bringing the exploits and achievements of their leading players". According to this claim we evaluate the attitude of TV audience to prefer matches involving players with extraordinary skill. We indicate by a dummy Superstar matches involving teams with top players recognized by one of the following prizes: European, African and South American Golden Ball28, FIFA World Player of the Year and the Best Goal Scorer $^{29}$. Obviously, the expected sign is positive.

\footnotetext{
${ }^{26}$ Betting odds on the expectation of the number of goals scored are archived by Football-Data that provides the average value of odds for a number of bookmakers varying from 4 to 47 .

27 Data are easily retrievable on http://www.football-data.co.uk/italym.php and related notes on http://www.football-data.co.uk/notes.txt (March, 2013).

${ }^{28}$ Until 1995 the Golden Ball award was exclusive for European football players. From 1995 to 2007 the prize was extended to players from all of the world if they played in a European team. From 2007 all players without
} 
Di Domizio, Marco. Football on TV: an empirical analysis on the italian couch potato attitudes.

Another explicative variable refers to the particular attitude of certain matches to generate greater appeal because of geographical reasons; this is the case of matches played by team located in the same region or in the same city. We then introduce a dummy Derby in order to seize the effect on TV audience. Again, a variable Population tries to catch the market size effect on Share as suggested by Cairns (1987) and Buraimo and Simmons (2006) with respect to gate attendance. We consider the sum of the home and away team town population referring to the residents at the middle of the season under investigation (31 ${ }^{\text {th }}$ December 2009); data are published by Italian National Institute of Statistics (ISTAT) ${ }^{30}$. To finish we consider dummy variables related to the matches played by at least one of the three Italian top teams for number of titles won and number of supporters (Inter, Juventus and Milan). These dummy variables ought to identify specific attitudes of top teams in producing oversized TV audience, net of the effects of other variables. The three teams are those that first negotiated the pay-per-view TV rights individually invoking, as mentioned above, their crucial role in determining the TV audience success of championship events. Table 1 resumes main descriptive statistics of the non dummies variables.

\begin{tabular}{|c|c|c|c|c|c|}
\hline Variable & Avg & Min & Max & $\begin{array}{l}\text { Std } \\
\text { Dev }\end{array}$ & Source \\
\hline Share & 1.732 & 0.000 & 12.250 & 2.021 & Lega Serie A \\
\hline Population (in log) & 13.533 & 11.944 & 14.825 & 0.616 & ISTAT \\
\hline Combined Wages & 0.951 & 0.124 & 11.484 & 1.452 & $\begin{array}{c}\text { La Gazzetta dello } \\
\text { Sport }\end{array}$ \\
\hline $\begin{array}{l}\text { Absolute Probability } \\
\text { Difference }\end{array}$ & 0.277 & 0.000 & 0.824 & 0.184 & \\
\hline Home Team Win Probability & 0.450 & 0.044 & 0.860 & 0.152 & Football Data \\
\hline Away Team Win Probability & 0.269 & 0.036 & 0.851 & 0.132 & \\
\hline Over 2.5 & 1.954 & 1.31 & 2.38 & 0.189 & \\
\hline
\end{tabular}

\footnotetext{
limitations [see Almanacco Illustrato del Calcio (2010)]. For the European Golden Ball we consider players ranked in the first three positions at last once in their career.

${ }^{29}$ In the season 2009/10 the players involved are Beckam (Milan), Buffon (Juventus), Eto'o (Inter), Ronaldinho (Milan) and Totti (Roma). Note that the dummy equals 1 if at least one of the formers played the match from the first minute.

${ }^{30}$ ISTAT, Demographic Indicators, available in www.demo.istat.it (July, 2012). Note that town population of Inter, Milan, Juventus, Genoa, Sampdoria, Roma, Lazio and Chievo Verona was corrected (divided by two) to take into account that Milano, Genova, Roma, Torino and Verona host two teams. In addition, even if Chievo is a little neighbourhood of Verona, having about 4,500 residents (according to the local parish), we consider the aggregate town data. Not significant difference in estimation results comes from the use of the two alternative measure.
} 
Di Domizio, Marco. Football on TV: an empirical analysis on the italian couch potato attitudes.

\section{ESTIMATION RESULTS}

We use ordinary least-squares regression (OLS) with correction for heteroschedasticity to estimate the statistical significance and the size of the effect of selected variables on TV audience. We first concentrate on 231 matches played contemporary and broadcasted only by SKY CALCIO channel. Successively, we add data on 42 matches played contemporary and broadcasted both on SKY CALCIO and SKY SPORT channels, introducing the dummy Plus. Finally, we extend the analysis to the 380 matches introducing the remaining 107 matches played in advance or postponed signalled by the dummy Advanced and Postponed. The results of the three estimations are summarized, respectively, in the following tables 2, 3 and 4. In each table we distinguish two models (A and $B$ ) diverging only by the use of Home Team Win Probability (model A) instead of Away Team Win Probability (model B), both in level and in squared values.

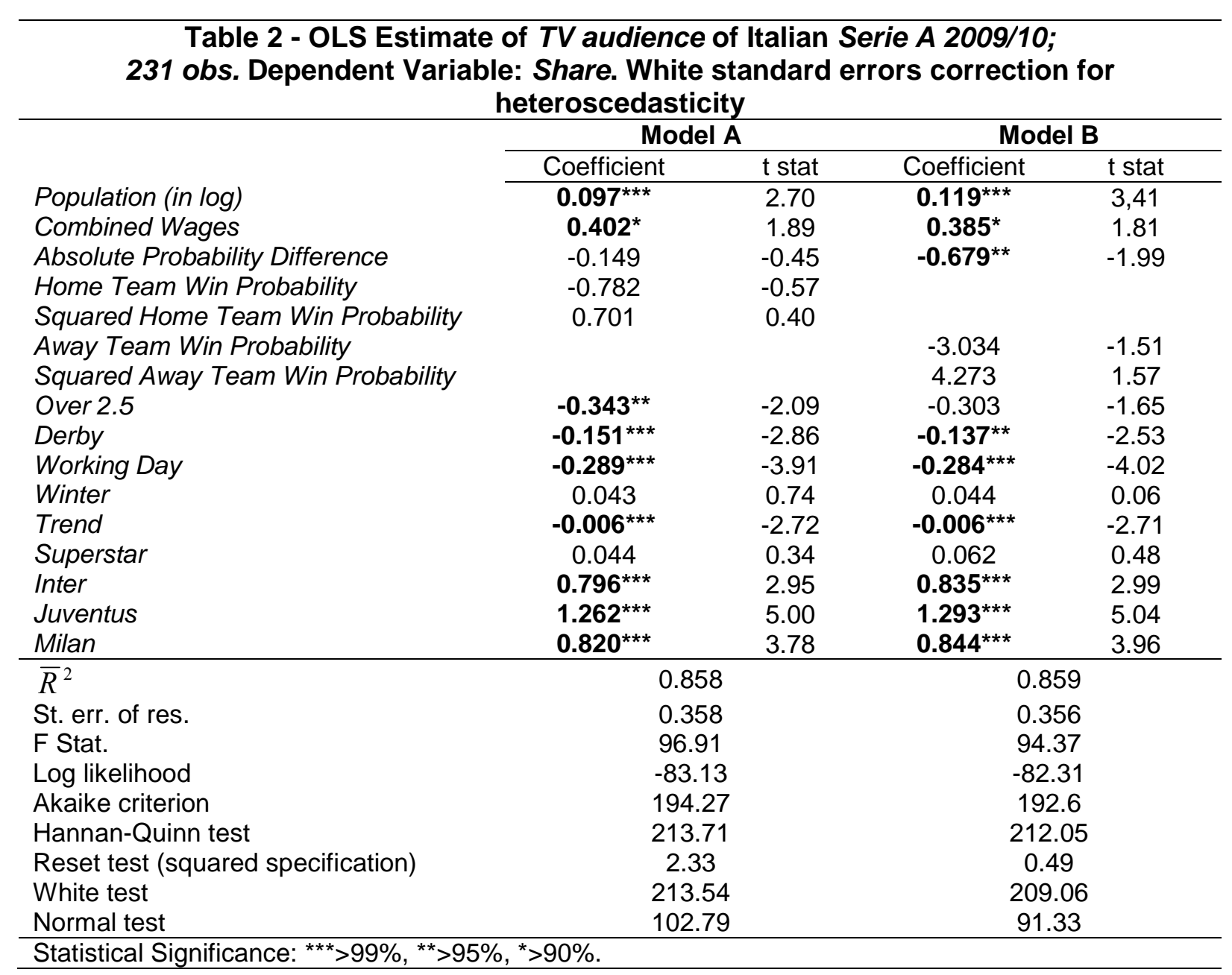

Table 3 - OLS Estimate of TV audience of Italian Serie A 2009/10; 273 obs. Dependent Variable: Share. White standard errors correction for heteroscedasticity

\begin{tabular}{|c|c|c|c|c|}
\hline & \multicolumn{2}{|c|}{ Model A } & \multicolumn{2}{|c|}{ Model B } \\
\hline & Coefficient & t stat & Coefficient & t stat \\
\hline Population (in log) & $0.094^{\star * \star}$ & 2.89 & $0.136^{\star \star \star}$ & 3.91 \\
\hline Combined Wages & $0.497^{\star *}$ & 2.55 & $0.501^{\star \star *}$ & 2.64 \\
\hline Absolute Probability Difference & 0.340 & 0.81 & $-0.996^{\star \star}$ & -2.44 \\
\hline Home Team Win Probability & -0.611 & -0.49 & & \\
\hline
\end{tabular}

Papeles de Europa 
Di Domizio, Marco. Football on TV: an empirical analysis on the italian couch potato attitudes.

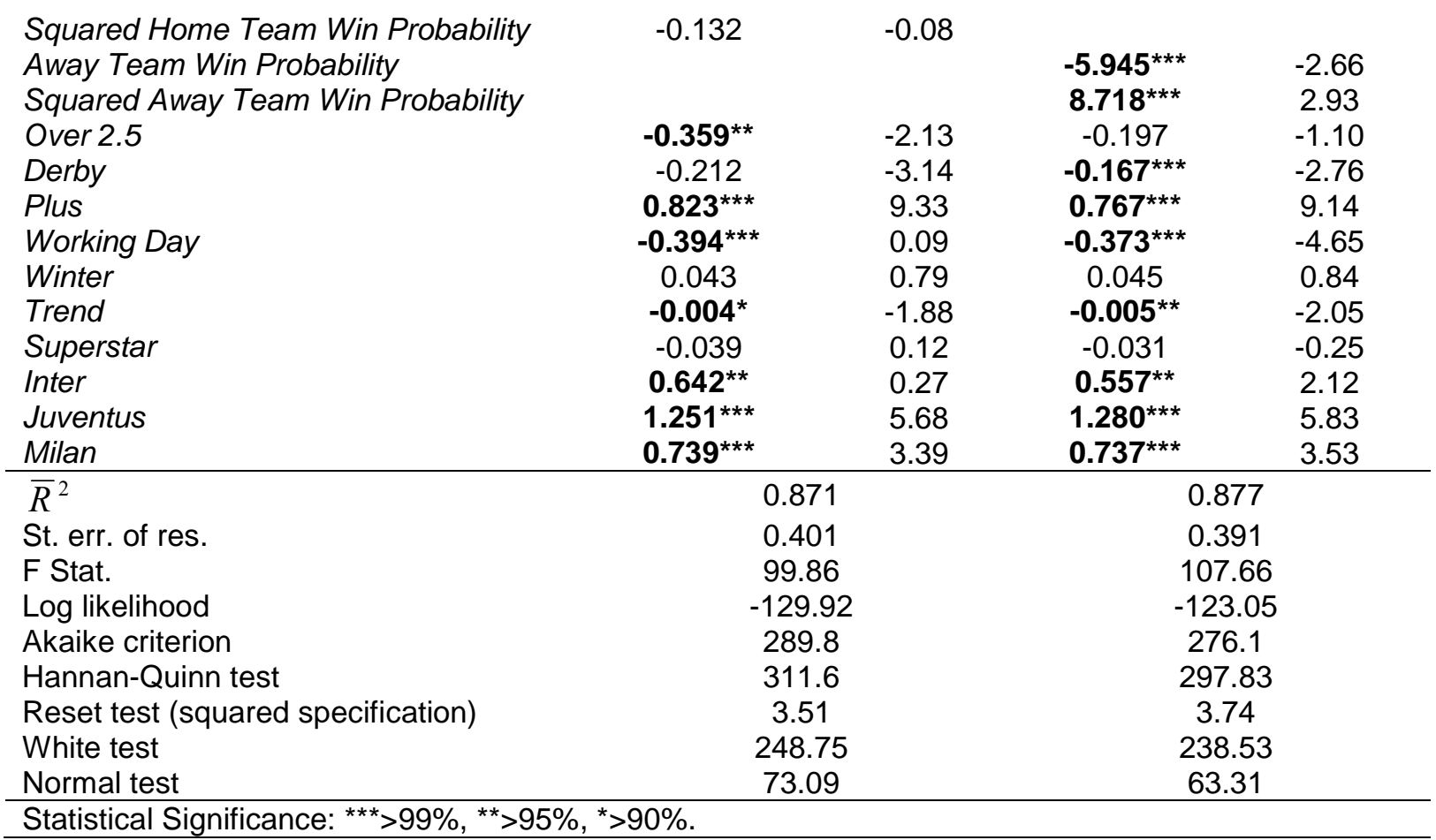

Table 4 - OLS Estimate of TV audience of Italian Serie A 2009/10; 380 obs. Dependent Variable: Share. White standard errors correction for heteroscedasticity

\begin{tabular}{|c|c|c|c|c|}
\hline & \multicolumn{2}{|c|}{ Model A } & \multicolumn{2}{|c|}{ Model B } \\
\hline & Coefficient & t stat & Coefficient & t stat \\
\hline Population (in log) & $0.174^{\star \star \star}$ & 4.71 & $0.164^{\star \star \star}$ & 4.17 \\
\hline Combined Wages & $0.401^{\star \star \star}$ & 5.55 & $0.366^{\star \star \star}$ & 4.92 \\
\hline Absolute Probability Difference & -0.387 & -0.71 & $-1.218^{\star \star}$ & -2.55 \\
\hline Home Team Win Probability & $-5.969^{\star \star \star}$ & -2.61 & & \\
\hline Squared Home Team Win Probability & $5.998^{\star \star}$ & 2.05 & & \\
\hline Away Team Win Probability & & & $-5.971^{\star \star \star}$ & -2.75 \\
\hline Squared Away Team Win Probability & & & $9.433^{\star \star *}$ & 3.41 \\
\hline Over 2.5 & -0.162 & -0.64 & -0.270 & -1.18 \\
\hline Derby & 0.182 & 0.68 & 0.231 & 0.85 \\
\hline Advanced and Postponed & $1.801^{\star \star \star}$ & 14.28 & $1.800^{\star \star \star}$ & 14.62 \\
\hline Plus & $0.795^{\star \star \star}$ & 8.92 & $0.802^{\star \star \star}$ & 8.59 \\
\hline Working Day & $-0.653^{\star \star \star}$ & -5.37 & $-0.668^{\star \star \star}$ & -5.44 \\
\hline Winter & -0.087 & -1.14 & -0.098 & -1.25 \\
\hline Trend & $-0.011^{\star *}$ & -2.55 & $-0.011^{\star \star \star}$ & -1.26 \\
\hline Superstar & $0.325^{\star}$ & 1.89 & $0.367^{\star *}$ & 2.04 \\
\hline Inter & $0.688^{\star *}$ & 0.04 & $0.848^{\star \star}$ & 2.57 \\
\hline Juventus & $1.116^{\star \star \star}$ & 4.73 & $1.213^{\star \star \star}$ & 5.28 \\
\hline Milan & 0.210 & 0.74 & 0.316 & 1.18 \\
\hline $\bar{R}^{2}$ & \multicolumn{2}{|c|}{0.923} & \multicolumn{2}{|c|}{0.922} \\
\hline St. err. of res. & \multirow{2}{*}{\multicolumn{2}{|c|}{$\begin{array}{c}0.739 \\
183.04\end{array}$}} & \multirow{2}{*}{\multicolumn{2}{|c|}{$\begin{array}{c}0.743 \\
188.31\end{array}$}} \\
\hline F Stat. & & & & \\
\hline Log likelihood & \multicolumn{2}{|c|}{-416.56} & \multicolumn{2}{|c|}{-418.02} \\
\hline Akaike criterion & \multicolumn{2}{|c|}{865.12} & \multicolumn{2}{|c|}{868.05} \\
\hline Hannan-Quinn test & \multicolumn{2}{|c|}{890.14} & \multicolumn{2}{|c|}{893.06} \\
\hline Reset test (squared specification) & \multicolumn{2}{|c|}{5.05} & \multicolumn{2}{|c|}{3.43} \\
\hline White test & \multicolumn{2}{|c|}{287.86} & \multicolumn{2}{|c|}{288.21} \\
\hline Normal test & \multicolumn{2}{|c|}{187.28} & \multicolumn{2}{|c|}{186.13} \\
\hline
\end{tabular}


Di Domizio, Marco. Football on TV: an empirical analysis on the italian couch potato attitudes.

We concentrate on results for which statistical significance is not dependent on sample selection. This way we note the role of the market size, approximated by log of Population, of the average quality of the match, synthesized by the Combined Wages, and the time collocation of matches, are of influence in determining the size of TV audience for football matches. As expected, it emerges that both market size and quality of teams are positively correlated with Share, and the magnitude lightly depends on the samples. From the market size perspective, being the variable Population expressed in logs, the coefficient is the elasticity of Share with respect to the market size; it ranges between 0.097 (model A with 231 observations) and 0.174 (model A with 380 observations). With respect to the match quality, the coefficient of Combined Wages is of the expected (positive) sign, but the variable has not a prominent role in determining the success of TV audience. This idea is supported by the fact that an increase in one standard deviation of the Combined Wages variable rises the Share - ceteris paribus - between 0.53 and 0.72 per cent, depending on the model selection. From the match quality perspective the superstar effect appears significant and in the expected direction only in the estimation on the 380 matches, while the coefficients of dummy Superstar is not statistically significant for the reduced samples. Another interesting result is that the working day collocation of matches is of relevance in determining the level of the Share. The audience of matches played during the week is low if compared with those played on Saturday or Sunday, and the loss may be quantified in a range between 0.284 and 0.668 . This is probably the effect of the other channels' "counter-programming», surely more articulated in respect to the weekend. To confirm the crucial role of the TV programming collocation note that matches played in advance or postponed have a Share of 1.8 extra points ${ }^{31}$. Interesting results emerge with respect to the uncertainty of outcome issue. We note that the Absolute Probability Difference variable is of statistical significance only in models $B$, and its expected (negative) effect is increasing in the number of sample size. At the same time we can not ignore that, when the uncertainty of outcome hypothesis appears to impact at its maximum level - model B of table 4 - its effect on Share is not crucial. This idea may be suggested by the calculus of the rise in the Share provoked by a one standard deviation reduction in Absolute Probability Difference; it is quantified in about 0.22 points, one tenth of the standard deviation of Share. In the same direction we can interpret results related to the teams' probabilities of win, particularly those emerging from the larger sample size. Being coefficients associated to Home Team Win Probability and Away Team Win Probability negative on the level term, and positive on the quadratic term, a $U$-shaped relationship appears between the home and away team expected victory and TV audience. The minimum of the U-shaped function falls around 0.497 and 0.316 , respectively for the home team and away team probability to win. In general, when the probability of win increases the Share reduces, and this relationship acts for a wide range of the Home Team Win Probability (about 63\%) and the Away Team Win Probability (70\%). This result contrasts with that obtained in our previous analysis [Di Domizio (2012)] when uncertainty of outcome proxy and teams probabilities of win were not included in the estimation jointly. Of course, the estimation outcome must be taken with a grain of salt; in fact, when the OLS model applies to the most homogeneous sample (231 obs.), both probabilities are not statistically significant. Of relevance is that both models, for each sample size, confirm the crucial role of top teams. With the exemption of Milan in the larger

\footnotetext{
${ }^{31}$ In the OLS model we do not consider potential bias determined by the selection of matches to broadcast in advance or to postpone.
} 
Di Domizio, Marco. Football on TV: an empirical analysis on the italian couch potato attitudes.

sample, all dummies associated to the top teams (Inter, Juventus and Milan) are of statistical significance and their magnitude is not negligible. In particular, when Juventus matches are broadcasted on TV, the Share increases for about 1.25 points, while for Inter and Milan the rise is ranged from 0.55-0.85 and 0.73-0.84 respectively. For almost all the remaining variables the statistical significance is rejected with the exemption of the variables Trend which coefficient is negative, indicating that the audience reduces when the season goes by, and Over 2.5. The second is of statistical significance only in models A for samples of 231 and 273 observations, although its effect is very poor. As made previously for other variables, if we simulate a reduction in Over 2.5 of one standard deviation ${ }^{32}$, the increase in audience is of about 0.06 points.

\section{CONCLUSIONS}

This paper aims at investigating the relationship between televised football matches and TV audience. We concentrate on season $2009 / 10$ of the Italian Serie $A$ championship testing for the statistical significance and magnitude of several independent variables with respect to the satellite television share. We estimate two OLS models for different samples, introducing variables summarizing the market size, the quality of the match, the closeness of the game, the TV programming arrangement, the time and seasonal placement, and some team-specific dummies, in order to test if theoretical prescriptions on the relationship between sporting context and the appeal of the match are confirmed.

Several relationships are of statistical significance and of the expected signs; particularly we refer to that associated with market size, to the quality of the match and to the TV programming and seasonal placement of the matches. More complicated is the explanation of the relationships with variables summarizing the closeness of the match attitude. Using data of the betting market and gathering probabilities of bookmakers associated to the matches results, we introduce several explicative variables evaluating the uncertainty of outcome trying to isolate their effect on TV audience. The results confirm, for the Italian championship, some peculiarities emerging from other British and Spanish contexts, such as the validation of the uncertainty of outcome hypothesis, but its position is not crucial in determining the success of TV audience. The idea is a consequence of the scarce rise in the Share obtained by a one standard deviation reduction in Absolute Probability Difference; the simulation seizes it in about 0.22 points, one tenth of the standard deviation of Share. Of relevance is the result on the relationships between Share and teams probabilities of win. Being coefficients associated to Home Team Win Probability and Away Team Win Probability negative on the level term, and positive on the quadratic term, a $U$-shaped relationship appears between the home and away team expected victory and TV audience. This result contrasts with that obtained in previous analysis when uncertainty of outcome proxies and teams probabilities of win were included in the estimation separately. When the probability of win increases the Share reduces for a wide range of the Home Team Win Probability (about 63\%) and the Away Team Win Probability (70\%). For the remaining range we have the opposite result, and it may be justified by considering that, since for high values of the probability of win (both for the home and away team) the relationship with the

\footnotetext{
${ }^{32}$ Remember that an increase in the odd Over 2.5 implies a reduced expectation of goals scored.
} 
Di Domizio, Marco. Football on TV: an empirical analysis on the italian couch potato attitudes.

uncertainty of outcome is negative, TV audience is committed just like stadium fans, and mainly interested in own team performances. An alternative explanation bases on the «David versus Goliath» hypothesis for which the couch potato hopes to participate to the upset of the top ranked teams. The two explanations are consistent with the statistical significance and the magnitude of the coefficients associated with the dummies Inter, Juventus and Milan. When one of the top ranked teams plays, and the match is broadcasted on satellite television the Share increases, particularly for Juventus which effect may be quantified around 1.25 points.

The analysis of data on season $2009 / 10$ generally confirms that performed on the previous season $2008 / 09$, even though some peculiarities emerge with respect to the uncertainty of outcome issue. We may assert that more close contexts are important in determining the interest on sporting events, also on Italian TV audience perspective, but they are not crucial. This contrasts the position of the law 9/2008 (Gentiloni-Melandri) affirming that the new regulation of TV rights must be founded on the ground of competitive balance, in order to preserve the interest (and then the commercial value) of the championship. Our analysis suggests that the connection more uncertainty of outcome=more interest operates only partially from the couch potato perspective, and then its presumed less committed nature is not confirmed on empirical ground. Does it means that the competitive balance has not commercial appeal? Does it means that the actions competitive balance-improving are detrimental with respect to the business profile? Our answer is absolutely not, but it is essential to recognize to the competitive balance the character of meritorious good that must be protected leaving aside the individual preferences of top ranked teams. This to confirm the social relevance of football emerging from the European Parliament Resolution 8 May 2008 based on the White Paper on Sport [COM (2007) 391] and so long debated in the literature ${ }^{33}$. If so the TV rights must not be considered as a commodity which equilibrium allocation in terms of prices and quantities has to be determined by the market forces. The resulting competitive balance equilibrium level could be dangerous for the league survival.

\footnotetext{
${ }^{33}$ See Caruso (2008) and Arnaut (2006).
} 
Di Domizio, Marco. Football on TV: an empirical analysis on the italian couch potato attitudes.

\section{REFERENCES}

K. Alavy, A. Gaskell, S. Leach and S. Szymanski, On the Edge of Your Seat: Demand for Football on Television and the Uncertainty of Outcome Hypothesis, in International Journal of Sport Finance, n. 5, 2010, 75-95.

J. Albert, R.H. Koning (eds.), Statistical Thinking in Sports, Chapman \& Hall, Boca Raton (FL, USA), 2008.

G. Allan, G. RoY, Does Television Crowd Out Spectators? New Evidence From The Scottish Premiere League, in Journal of Sports Economics, vol. 9, n. 6, 2008, 592-605.

C. AnAgnostopulos (eds), Contextualising Research in Sport: An Internatinal Perspective, Athens Institute for Education and Research, Athens, 2012

W. ANDREFF, J.F. BouRG, Broadcasting Rights and Competition in European Football, in C. Jeanrenaud, S. Kesenne (eds.), The Economics of Sport and the Media, Edward Elgar Publishing, Cheltenham (UK), 2006, 37-65.

W. AndRefF, S. SzYMANSKI (eds.), Handbook on the Economics of Sport, Edward Elgar, Cheltenham (UK), 2006.

J.L. ARNAUt, Rapporto Indipendente sullo Sport in Europa, 2006.

M. Baimbridge, S. CAmERon, P.M. Dawson, Satellite Television And The Demand For Football: A Whole New Game?, in Scottish Journal of Political Economy, vol. 43, n. 3, 1996, 317-333.

O. BeHA, A. Di CARO, Indagine sul calcio, Biblioteca Universale Rizzoli, Milano 2006.

T. Boeri, C. Bisoni, Calciopoli anno zero, in F. Bof, F. Montanari, G. Silvestri (eds.), Il Management del Calcio, Franco Angeli, Milano, 2008, 63-74.

F. BOF, F. MontanARI, G. Silvestri, (eds.), II Management del Calcio, Franco Angeli, Milano, 2008.

J. Borland, R. Macdonald, Demand for Sport, in Oxford Review of Economic Policy, vol. 19, n. 4, 2003, 478-502.

L. Brandes, E. Franck, Who Made Who? An Empirical Analysis of Competitive Balance in European Soccer Leagues, in Eastern Economic Journal, vol. 33, n. 3, Summer 2007, 379-402.

B. BuRAIMo, The Demand for Sport Broadcasting, in W. ANDREFF, S. SzYMANSKI (eds.), Handbook on the Economics of Sport, Edward Elgar, Cheltenham (UK), 2006, 100-111.

B. BURAIMO, D. FORREST, R. SIMMONS, Robust estimates of the impact of broadcasting on match attendance in football, Lancaster University Management School Working Papers, 2006/004, 1-26.

B. BuRAimo, R. Simmons, Market size and attendance in English Premiere League football, in Lancaster University Management School Working Paper, n. 3, 2006, 1-28.

B. Buraimo, R. Simmons, A Tale Of Two Audiences: Spectators, Television Viewers And Outcome Uncertainty In Spanish Football, Lancaster University Management School Working Papers, 2007/43, 1-25.

B. Buraimo, R. Simmons, Do Sport Fans Really Value Uncertainty of Outcome? Evidence from the English Premiere League, in International Journal of Sport Finance, vol. 3, n. 3, 2008, 146-155.

J.A. CAIRNS, Evaluating changes in league structure: the reorganization of the Scottish Football League, in Applied Economics, vol. 19, 1987, 259-275.

R. CARuso, Il Calcio tra Mercato, Relazioni e Coercizione, in Rivista di Diritto ed Economia dello Sport, vol. 4, n. 1, 2008, 71-88. 
Di Domizio, Marco. Football on TV: an empirical analysis on the italian couch potato attitudes.

R. Caruso, M. DI Domizio, Hooliganism and demand for football in Italy. Evidence for the period 1962-2011, in Economic Policy Institute Working Paper Series, n. 62, Catholic University of the Sacred Heart - Milan, 2012, 1-44.

M. Cave, R.W. Crandall, Sports Rights and the Broadcast Industry, in The Economic Journal, Vol. 111, n. 469, 2001, F4-F26.

D. CZARnitZKI, G. StAdTMANN, Uncertainty of Outcome Versus Reputation: Empirical Evidence for the First German Football Division, in Empirical Economics, vol. 27, n. 1, 2002, 101-112.

DeloitTE, Captains of Industry - Football Money League, March 2013.

M. Dı Domızı, La Domanda di Calcio in Italia: Serie A 1962-2006, in Rivista di Diritto ed Economia dello Sport, vol. 3, n. 1, 2007, 71-90.

M. Dı Domızı, Competitive Balance and TV Audience: An Empirical Analysis on the Italian Serie A, in C. ANAGNOStopulos (eds), Contextualising Research in Sport: An Internatinal Perspective, Athens Institute for Education and Research, Athens, 2012, 155-174.

S. DoBson, J. GodDARD, The Economics of Football, University Press, Cambridge (UK), 2001.

P. Downward, A. Dawson, The Economics of Professional Football, Routledge, London, 2000.

M. El HodIRI, J. QuIRK, An Economic Model of a Professional Sports League, in Journal of Political Economy, vol. 79, n. 6, 1971, 1302-1319.

FIGC, Report Calcio 2012.

J. FIgus DIAZ, V. ForTI, La Disciplina Antitrust Della Nuova Legislazione Sui Diritti Di Trasmissione: Quid Novi Sub Sole?, in Rivista di Diritto ed Economia dello Sport, vol. 4, n. 2, 2008, 13-35.

D. FORREST, R. SIMMONS, Outcome uncertainty and attendance demand in sport: the case of English soccer, in The Statistician, vol. 51, n. 2, 2002, 229-241.

D. ForRest, R. Simmons, New Issues In Attendance Demand; The Case Of English Soccer, in Journal of Sports Economics, vol.7, n. 3, 2006, 247-266.

D. Forrest, R. Simmons, B. Buraimo, Outcome Uncertainty And The Couch Potato Audience, in Scottish Journal of Political Economy, vol. 52, n. 4, 2005, 641-661.

D. ForRest, R. Simmons, S. SZYMANSKI, Broadcasting, Attendance And The Inefficiency Of Cartels, in Review of Industrial Organization, vol. 24, n. 3, 2004, 243-265.

R.D. FORT, Sports Economics (2 ${ }^{\text {nd }}$ edition), Pearson Prentice Hall, Upper Saddle River (NJ, USA), 2006.

J. Garcia, P. RodrigueZ, The Determinants of Football Match Attendance Revisited: Empirical Evidence From the Spanish Football League, in Journal of Sports Economics, vol. 3, n. 18, 2003, 18-38.

B. Gerrard, Competitive Balance and the Sports Media Rights Market: What are the Real Issues?, in C. JeANRENAUD, S. KeSENNE (eds.), The Economics of Sport and the Media, Edward Elgar Publishing, Cheltenham (UK), 2006, 26-36.

M. HaAn, R.H. Koning, A. van Witteloostulun, Competitive Balance in National European Soccer Competitions, in J. AlBeRT, R. H. KoNING (eds.), Statistical Thinking in Sports, Chapman \& Hall, Boca Raton (FL, USA), 2008, 63-76.

S. Hall, S. SzYMAnSKI, A. Zimbalist, Testing Causality Between Team Performance and Payroll: The Case of Major League Baseball and English Soccer, in Journal of Sports Economics, vol. 3, n. 2, 2002, 149-168.

T. HoEN, S. SZYMANSKI, The Americanization of European Football, in Economic Policy, vol. 28, April, 2001, 205-233. 
Di Domizio, Marco. Football on TV: an empirical analysis on the italian couch potato attitudes.

C. Jeanrenaud, S. Kesenne, Sport and the Media: An Overview, in C. Jeanrenaud, S. Kesenne (eds.), The Economics of Sport and the Media, Edward Elgar Publishing, Cheltenham (UK), 2006, 1-25.

C. Jeanrenaud, S. Kesenne (eds.), The Economics of Sport and the Media, Edward Elgar Publishing, Cheltenham (UK), 2006.

U. Lago, A. Baroncelli, S. Szymanski (eds.), Il Business del Calcio, Egea, Milano, 2004.

M. Leeds, P. Von Allmen, The Economics of Sport, Pearson-Addison Wesley, Boston, 2005.

F. MONTANARI, G. Silvestri, Le determinanti della retribuzione tra risultati e caratteristiche individuali: il caso del campionato di calcio di Serie A, in Rivista di Diritto ed Economia dello Sport, vol. 3, n. 1, 2007, 91-106.

W.C. NeALe, The Peculiar Economics of Professional Sports, in Quarterly Journal of Economics, vol. 78, n. 1, 1964, 1-14.

M. NiCOLIELLO, Reddito e capitale nelle società di calcio: la massima serie italiana 1998-2007, in Rivista di Diritto ed Economia dello Sport, vol. 4, n. 2, 2008, 67-94.

R. NolL, Broadcasting and Team Sports, in Scottish Journal of Political Economy, Vol. 54, n.3. July 2007, 400-421.

D.A. PeEL, D. A. Thomas, The demand for football: Some evidence on outcome uncertainty, in Empirical Economics, vol. 17, n. 2, 1992, 323-331.

T. Peeters, Broadcasting Rights and Competitive Balance in European Soccer, Department of Economics Research Paper n. 9, University of Antwerp, 2009.

L. PÉrez, P. Rodriguez, The Impact of Broadcasts of Live Sporting Events on Television Audience Sizes, Paper presented at the XIV IASE Conference, London, 2012.

S. Perlasca, Collective Selling of Broadcast Rights in Team Sports, in W. ANDREFf, S. SZYMANSKI (eds.), Handbook on the Economics of Sport, Edward Elgar, Cheltenham (UK), 2006, 719-729.

P.F. POPE, D.A. ThOMAS, Information, prices and efficiency in a fixed-odds betting market, in Economics, vol. 56, n. 223, 1989, 323-341.

RISOLUZIONE DEL PARLAMENTO EUROPEO DELL'8 MAGGIO 2008 SUL LIBRO BIANCO SULLO SPORT [2007/2661 (INI)], in Rivista di Diritto ed Economia dello Sport, vol. 4, n. 2, 2008, 123-151.

R. Sandy, P. Sloane, M.S. Rosentraub, The Economics of Sport - An International Perspective, Palgrave Macmillan, New York, 2004.

S.K.S. DE SANTANA, A.S. DA SILVA, The Determinants of Demand in Football Matches During the 2007 Brazilian Championship, IASA/NAASE Working Paper Series, No. 09-06, June 2009.

P.J. SLoANE, The Economics of Professional Football: The Football Club as a Utility Maximiser, in Scottish Journal of Political Economy, vol. 18, n. 2, 1971, 121-146.

S. SZYMANSKI, Income Inequality, Competitive Balance and the Attractiveness of Team Sports: Some Evidence and a Natural Experiment from English Soccer, in The Economic Journal, vol. 111, n. 469, 2001, F69-F84.

S. SZYMANSKI, Economic Design of Sporting Contest, in Journal of Economic Literature, vol. 41, n. 4, 2003, 1137-1187.

S. SZYMANSKI, La relazione tra posizione competitiva e posizione reddituale: quali sono le squadre migliori?, in U. LAGO, A. BARONCELLI, S. SZYMANSKI (eds.) II Business del Calcio, Franco Angeli, Milano, 2004, 149-166.

R. TAVELLA, Il libro nero del calcio italiano, Newton \& Compton, Roma, 2006. 
Di Domizio, Marco. Football on TV: an empirical analysis on the italian couch potato attitudes.

A. TONAzZI, Competition Policy and the Commercialization of Sport Broadcasting Rights, in International Journal of the Economics of Business, vol. 10, n. 1, 2003, 17-34.

V. VentuRELLI, Costi e ricavi, investimenti e finanziamenti nelle società di calcio, in F. Bof, F. Montanari, G. Silvestri, (eds.), Il Management del Calcio, Franco Angeli, Milano, 2008, 34-62.

J.G. VILLAR, P.R. GUERRERO, Sports Attendance: A Survey of the Literature 19732007, in Rivista di Diritto e di Economia dello Sport, vol. 5, n. 2, 2009, 112-151. 